\title{
A COMPARISON OF THE POTENCY OF THE OXIME HLÖ-7 AND CURRENTLY USED OXIMES (HI-6, PRALIDOXIME, OBIDOXIME) TO REACTIVATE NERVE AGENT-INHIBITED RAT BRAIN ACETYLCHOLINESTERASE BY IN VITRO METHODS
}

\author{
Kamil Kuča, Jiří Cabal, Jiři Kassa, Daniel Jun, Martina Hrabinová
}

University of Defence in Brno, Faculty of Military Health Sciences in Hradec Králové, Czech Republic: Department of Toxicology

\begin{abstract}
Summary: 1. The efficacy of the oxime HLö-7 and currently used oximes (pralidoxime, obidoxime, HI-6) to reactivate acetylcholinesterase inhibited by various nerve agents (sarin, tabun, cyclosarin, VX) was tested by in vitro methods. 2 . Both H oximes (HLö-7, HI-6) were found to be more efficacious reactivators of sarin and VX-inhibited acetylcholinesterase than pralidoxime and obidoxime. On the other hand, their potency to reactivate tabun-inhibited acetylcholinesterase is very low and does not reach the reactivating efficacy of obidoxime. In the case of cyclosarin, the oxime HI- 6 was only found to be able to sufficiently reactivate cyclosarin-inhibited acetylcholinesterase in vitro. 3 . Thus, the oxime HLö-7 does not seem to be more efficacious reactivator of nerve agent-inhibited acetylcholinesterase than HI-6 according to in vitro evaluation of their reactivation potency and, therefore, it is not more suitable to be introduced for antidotal treatment of nerve agent-exposed people than HI-6.
\end{abstract}

Key words: Sarin; Cyclosarin; Tabun; VX; Obidoxime; Pralidoxime; HI-6; HLö-7; Acetylcholinesterase; Reactivation

\section{Introduction}

The highly toxic organophosphorus compounds, called nerve agents (sarin, soman, tabun, cyclosarin or agent VX), belong to the most dangerous chemical warfare agents. Their acute toxicity is based on the irreversible inhibition of the enzyme - acetylcholinesterase (AChE; Enzyme Code 3.1.1.7) and subsequent accumulation of the neuromediator acetylcholine at peripheral and central cholinergic sites $(14,17)$. AChE plays a key role in physiological function of the cholinergic nervous system and, therefore, its inhibition is life-endangering factor. Inhibitory effect is based on phosphorylation or phosphonylation of serine hydroxyl group at the esteratic site of the active site of the enzyme.

The antidotal treatment of acute poisoning with nerve agents is based on the administration of anticholinergic drugs to antagonize the overstimulation of cholinergic receptors caused by accumulated acetylcholine, and acetylcholinesterase reactivators to reactivate phosphonylated or phosphorylated AChE (3). According to experimental data, quaternary pyridinium aldoximes have been found to be the most promising agents to reactivate nerve agent-inhibited AChE (7). Monoquaternary pralidoxime (2-PAM, 2-hydroxyiminomethyl-1-methylpyridinium chloride) or more exten- ded bisquaternary compounds such as obidoxime [1,3-bis(4-hydroxyiminomethylpyridinium)-2-oxa-propane dichloride] and the oxime HI-6 [1-(2-hydroxyiminomethylpyridinium)-3-(4-carbamoylpyridinium)-2-oxa-propane dichloride] (Figure 1) belong to the fundamental representatives of these aldoximes.

Unfortunately, currently used oximes are not sufficiently effective against some nerve agents. They are not able to reactivate nerve agent-inhibited $\mathrm{AChE}$ regardless of the type of nerve agent used $(1,5,10)$. While pralidoxime and obidoxime have very low potency to reactivate soman and cyclosarin-inhibited $\mathrm{AChE}(8,9)$, the oxime HI-6 seems to be practically ineffective to reactivate tabun-inhibited AChE (19). Therefore, to find another bispyridinium oxime able to sufficiently reactivate nerve agent-inhibited AChE regardless of the type of nerve agent is still a very important task for medicine. Its solution may improve the efficacy of antidotal treatment of acute poisonings with nerve agents. The present study compares the reactivating efficacy of currently used oximes (pralidoxime, obidoxime, HI-6) and another asymmetric bisquaternary oxime, called HLö-7 [1(4-carbamoylpyridinium)-3-(2,4-bis hydroxyiminomethyl pyridinium)-2-oxa-propane dichloride] (Figure 1) against AChE inhibited by chosen nerve agents (VX, tabun, sarin, cyclosarin) by in vitro methods. 
<smiles>[X]c1cccc(C=N)[n+]1C</smiles>

Pralidoxime<smiles>C[n+]1ccc(C=N)cc1</smiles>

Obidoxime<smiles>C[n+]1ccc(C(N)=O)cc1</smiles>

HI-6<smiles>NC(=O)c1cc[n+](CO)cc1</smiles>

HLö-7

Fig. 1: Chemical structure of AChE reactivators.

\section{Methods}

\section{Animals}

Male albino Wistar rats weighing 180-200 g were purchased from Biotest Konárovice (Czech Republic). They were kept in an air-conditioned room $\left(22 \pm 1^{\circ} \mathrm{C}\right.$ and $50 \pm$ $10 \%$ relative humidity, with lights from 07.00 to 19.00 ) and were allowed free access to standard food and tap water ad libitum. Experiments were performed under the supervision of the Ethics Committee of Medical Faculty of Charles University and Faculty of Military Health Sciences of University of Defense, Czech Republic.

\section{Enzymes and chemicals}

After exsanguination of anaesthetized animals by decapitation (i.p. injection of urethane $1.5 \mathrm{~g} / \mathrm{kg}$ ), the rat brains were removed and used as a source of $\mathrm{AChE}$ after homogenization. All nerve agents (VX, tabun, sarin, cyclosarin) were obtained from the Military Technical Institute (Brno, Czech Republic) and were $89-95 \%$ pure. The purity was evaluated by acidimetric titration. The monopyridinium and bispyridinium oximes (pralidoxime, obidoxime, HI-6) were earlier synthesized at the Department of Toxicology of the Faculty of Military Health Sciences (Czech Republic). The oxime HLö-7 was kindly given by Prof. L. Szinicz from Institute of Pharmacology and Toxicology in Munich (Germany). Their purities were analysed using a HPLC technique. All other drugs and chemicals of analytical grade were obtained commercially and used without further purification.

\section{In vitro experiments}

Reactivation effectivity of the oximes has been tested in vitro on the model of $\mathrm{AChE}$ inhibited by VX agent, tabun, sarin or cyclosarin using standard reactivation test with electrometric instrumentation (11,18).

\section{Determination of percentage of reactivation}

The percentage of reactivation (\%R) was calculated from the measured activities of the intact enzyme $\mathrm{a}_{0}$, nerve agent-inhibited enzyme $a_{i}$, and reactivated enzyme $a_{r}$, using equation 1 . The enzyme activity was measured at room temperature $\left(25^{\circ} \mathrm{C}\right)$ and $\mathrm{pH}$ 7.6.

$$
\% R=\left[1-\left(a_{0}-a_{r}\right) /\left(a_{0}-a_{i}\right)\right] \times 100
$$

Determination of activity of intact AChE ( $\left.a_{0}\right)$

Rat brain homogenate $(0.5 \mathrm{ml})$ was added to a $0.3 \mathrm{M}$ sodium chloride solution $(20 \mathrm{ml})$. Then, $0.02 \mathrm{M}$ solution of acetylcholine iodide $(2.0 \mathrm{ml})$ was added and the system was adjusted with $0.3 \mathrm{M}$ sodium chloride solution to a total volume of $25.0 \mathrm{ml}$. The liberated acetic acid was titrated with $0.01 \mathrm{M}$ sodium hydroxide on an RTS 822 titrator (Radiometer, Denmark) in the $\mathrm{pH}$-stat mode $(\mathrm{pH} \mathrm{8.0)}$ at room temperature $\left(25^{\circ} \mathrm{C}\right)$. The ionic strength of the solution was rendered with sodium chloride at constant value $\mathrm{I}=0.25 \mathrm{M}$. The slope of the linear part of the time dependence of the sodium hydroxide used represents the activity of the intact enzyme (in fact, the initial rate of the enzymatic reaction).

Determination of activity of inhibited AChE $\left(a_{i}\right)$

Rat brain homogenate $(0.5 \mathrm{ml})$ was treated with aqueous solution of nerve agent $(0.5 \mathrm{ml})$ for $30 \mathrm{~min}$, which resulted in about 95\% inhibition of the enzyme. 0.02 $\mathrm{M}$ solution of acetylcholine iodide $(2.0 \mathrm{ml})$ was added and the mixture was adjusted to $25.0 \mathrm{ml}$ with $0.3 \mathrm{M}$ sodium chloride solution. The activity of the inhibited enzyme $\left(a_{\mathfrak{i}}\right)$ was immediately determined analogously as described in the previous experiment.

\section{Determination of activity of reactivated $A C h E\left(a_{r}\right)$}

Reactivation of the enzyme, inhibited in the above mentioned experiment, was performed immediately after the inhibition. A solution $(1.0 \mathrm{ml})$ of the reactivator was added to the enzyme in appropriate concentration in the range $1.10^{-7}-1.10^{-2} \mathrm{M}$. After $10 \mathrm{~min}$ reactivation at $25^{\circ} \mathrm{C}$, $0.02 \mathrm{M}$ solution of acetylcholine iodide $(2.0 \mathrm{ml})$ was added. The mixture was adjusted to $25.0 \mathrm{ml}$ with $0.3 \mathrm{M}$ sodium chloride solution and immediately afterwards the activity of the reactivated enzyme was determined as described in the previous experiments. According to our observation, the possibility of nerve agent-induced inhibition of released free enzyme during the reactivation of the enzyme is negligible.

\section{Calculation of rate and dissociation constants}

The measured values of enzyme activity in relationship to the used concentrations of reactivator were used for the calculation of rate and dissociation constants using equation 2: 


$$
\begin{aligned}
\% \mathrm{~A}= & \left(100 *\left(1-\operatorname{EXP}\left(-\mathrm{t} * \mathrm{k}_{\mathrm{R}}{ }^{*} \mathrm{C}_{\mathrm{R}} /\left(\mathrm{C}_{\mathrm{R}}+\mathrm{K}_{\mathrm{R}}\right)\right)\right)^{*}\right. \\
& \left.*\left(1-\mathrm{a}_{\mathrm{i}} / \mathrm{a}_{0}\right)+100 * \mathrm{a}_{\mathrm{i}} / \mathrm{a}_{0}\right) /\left(1+\left(\mathrm{C}_{\mathrm{S}} / \mathrm{K}_{\mathrm{M}}+1\right)^{*}\right. \\
& \left.* \mathrm{C}_{\mathrm{R}} /\left(\mathrm{K}_{\mathrm{dis}}{ }^{*} \mathrm{f}_{\mathrm{d}}\right)\right)
\end{aligned}
$$

where:

$\% \mathrm{~A}=$ percentage of enzyme activity after reactivation, when $100 \%=$ activity of intact enzyme

$\mathrm{t}=$ time of the reactivation

$\mathrm{k}_{\mathrm{R}}=$ pseudofirst order-rate constant of reactivation for $\mathrm{C}_{\mathrm{R}}=\infty$

$\mathrm{C}_{\mathrm{R}}=$ molar concentration of reactivator

$\mathrm{K}_{\mathrm{R}}=$ dissociation constant of the enzyme-inhibitor-reactivator complex

$\mathrm{a}_{\mathrm{i}}=$ activity of inhibited enzyme

$\mathrm{a}_{0}=$ activity of intact enzyme

$\mathrm{C}_{\mathrm{S}}=$ molar concentration of substrate

$\mathrm{K}_{\mathrm{M}}=$ dissociation constant of enzyme - substrate complex (Michaelis constant)

$\mathrm{K}_{\text {dis }}=$ dissociation constant of enzyme - reactivator complex $\mathrm{f}_{\mathrm{d}}=$ dilution constant calculated from the ratio of volume of substrate reaction and volume of reactivator reaction

${ }^{*}=$ multiplication

The first part of above mentioned equation (1-EXP $\left.\left(-t * k_{R}{ }^{*} C_{R} /\left(C_{R}+K_{R}\right)\right)\right)$ describes an increase in enzyme activity due to dephosphorylation of enzyme and the second part $\left(1+\left(\mathrm{C}_{\mathrm{S}} / \mathrm{K}_{\mathrm{M}}+1\right){ }^{*} \mathrm{C}_{\mathrm{R}} /\left(\mathrm{K}_{\mathrm{dis}}{ }^{*} \mathrm{f}_{\mathrm{d}}\right)\right)$ describes a decrease in enzyme activity due to a competitive reaction of reactivator and substrate about binding site of enzyme. Fraction $a_{i} / a_{0}$ introduces correction for subtotal inhibition of enzyme in equation 2. A computer program for non-linear regression was used to calculate reactivation parameters. Calculated parameters were $\mathrm{k}_{\mathrm{R}}, \mathrm{K}_{\mathrm{R}}$ and $\mathrm{K}_{\mathrm{dis}}$. Other parameters of equation were introduced as constants.

The second-order rate constant of reactivation $\left(\mathrm{k}_{\mathrm{r}}\right)$ was calculated using equation 3 :

$$
\mathrm{k}_{\mathrm{r}=\mathrm{k}_{\mathrm{R}}} / \mathrm{K}_{\mathrm{R}}
$$

\section{Determination of the dissociation constant of enzyme-reactivator complex}

Appropriate volume of $0.01 \mathrm{M}$ solution of the oxime was added to rat brain homogenate $(0.5 \mathrm{ml})$ so as to achieve the desired oxime concentration $\mathrm{C}_{\mathrm{R}}$ in the interval $5.10^{-5}$ $5.10^{-2} \mathrm{M}$. Then, $0.02 \mathrm{M}$ solution of acetylcholine iodide (2.0 $\mathrm{ml}$ ) was added, the mixture was adjusted to $25.0 \mathrm{ml}$ with $0.3 \mathrm{M}$ sodium chloride and the rate of the enzyme reaction (v) was immediately determined analogously as in the previous experiments. The dissociation constant $\left(\mathrm{K}_{\mathrm{dis}}\right)$ was obtained by non-linear regression from the dependence of $\mathrm{v}$ on $\mathrm{C}_{\mathrm{R}}$ using equation 4 :

$$
\mathrm{v}=\mathrm{v}_{\max } \times \mathrm{C}_{\mathrm{s}} /\left(\mathrm{C}_{\mathrm{s}}+\mathrm{K}_{\mathrm{M}} \times\left(1+\mathrm{C}_{\mathrm{R}} / \mathrm{K}_{\mathrm{dis}}\right)\right)
$$

where, in addition to the above-defined symbols, $v_{\max }$ denotes the maximum (limiting) rate of the enzymatic reaction, $\mathrm{C}_{\mathrm{s}}$ is the substrate concentration and $\mathrm{K}_{\mathrm{M}}$ is the Michaelis constant for hydrolysis of acetylcholine with $\operatorname{AChE}\left(1.9 .10^{-4} \mathrm{M}\right)$.

\section{Results}

The ability of tested monopyridinium and bispyridinium oximes to reactivate $\mathrm{AChE}$ inhibited by chosen nerve agents in vitro characterized by percentage of reactivation and kinetic parameters is summarized in Tables 1-4 and Figures 2-5.

Kinetics parameters shown in Tab. 1 characterize the ability of all studied oximes to reactivate VX-inhibited $\mathrm{AChE}$ in vitro. Concentration-reactivation relationship is expressed in Figure 2. The values of the dissociation constant $\left(K_{d i s}\right)$ indicating the affinity of oximes toward the noninhibited AChE show that the oxime HLö-7 has a higher affinity to the intact enzyme than commonly used obidoxime and pralidoxime as well as the oxime HI-6. The dissociation constant $K_{R}$ which characterizes affinity of oximes to the inhibited AChE (inhibitor-enzyme complex), indicates that the affinity of HLö-7 to the enzyme-inhibitor complex is higher than other studied oximes (HI-6, obidoxime, pralidoxime), too. The differences in the affinity of studied oximes to intact or inhibited enzyme correspond to the differences in the second-order rate constant of reactivation of VX-inhibited AChE $\left(\mathrm{k}_{\mathrm{r}}\right)$. The velocity of HLö-7 induced reactivation of $\mathrm{VX}$-inhibited $\mathrm{AChE}$ is much higher compared to other studied oximes. According to our results shown in Figure 2, the oxime HLö-7 has a higher potency to reactivate VX-inhibited AChE compared to other studied oximes at $10^{-5}$ and $10^{-4} \mathrm{M}$ that should be safe for human use.

Tab. 1: Kinetic parameters of the reactivation of VX-inhibited $\mathrm{AChE}$ in rat brain homogenate.

\begin{tabular}{|l|c|c|c|c|}
\hline Oxime & $\begin{array}{c}K_{\mathrm{DIS}} \\
{[\mu \mathrm{M}]}\end{array}$ & $\begin{array}{c}K_{\mathrm{R}} \\
{[\mu \mathrm{M}]}\end{array}$ & $\begin{array}{c}k_{\mathrm{R}} \\
{\left[\mathrm{min}^{-1}\right]}\end{array}$ & $\begin{array}{c}k_{\mathrm{r}} \\
{\left[\mathrm{min}^{-1} \mathrm{M}^{-1}\right]}\end{array}$ \\
\hline 2-PAM & 210 & 127 & 0.047 & 370 \\
\hline Obidoxime & 280 & 562 & 0.330 & 587 \\
\hline HI-6 & 24 & 130 & 0.191 & 1469 \\
\hline HLö-7 & 7 & 25 & 0.17 & 6800 \\
\hline
\end{tabular}

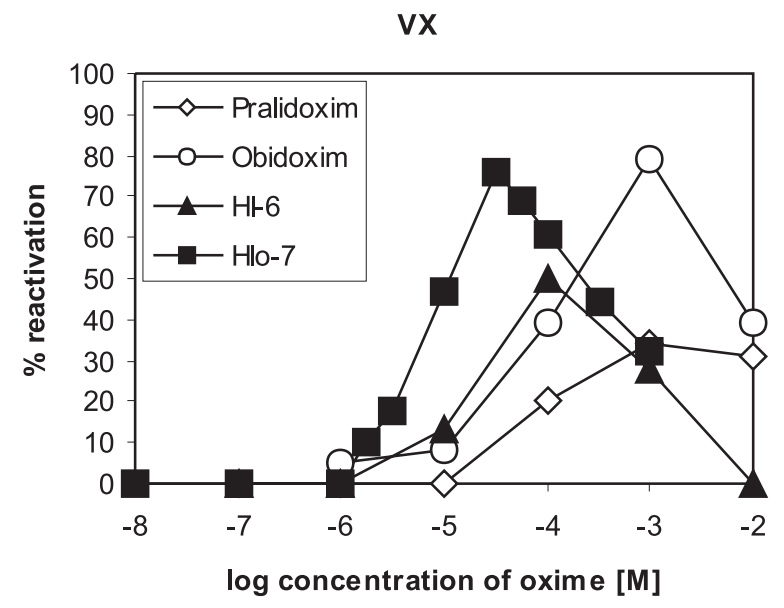

Fig. 2: Reactivation-concentration relationships of oximes to VX-inhibited AChE - semilogarithmic transformation. 
Tab. 2: Kinetic parameters of the reactivation of tabun-inhibited AChE in rat brain homogenate.

\begin{tabular}{|l|c|c|c|c|}
\hline Oxime & $\begin{array}{c}K_{\mathrm{DIS}} \\
{[\mu \mathrm{M}]}\end{array}$ & $\begin{array}{c}K_{\mathrm{R}} \\
{[\mu \mathrm{M}]}\end{array}$ & $\begin{array}{c}k_{\mathrm{R}} \\
{\left[\mathrm{min}^{-1}\right]}\end{array}$ & $\begin{array}{c}k_{\mathrm{r}} \\
{\left[\mathrm{min}^{-1} \mathrm{M}^{-1}\right]}\end{array}$ \\
\hline 2-PAM & 210 & 575 & 0.006 & 10 \\
\hline Obidoxime & 280 & 3 & 0.020 & 6250 \\
\hline HI-6 & 24 & 6 & 0.007 & 1111 \\
\hline HLö-7 & 7 & - & - & - \\
\hline
\end{tabular}

$(-)=$ not measurable values

Tabun

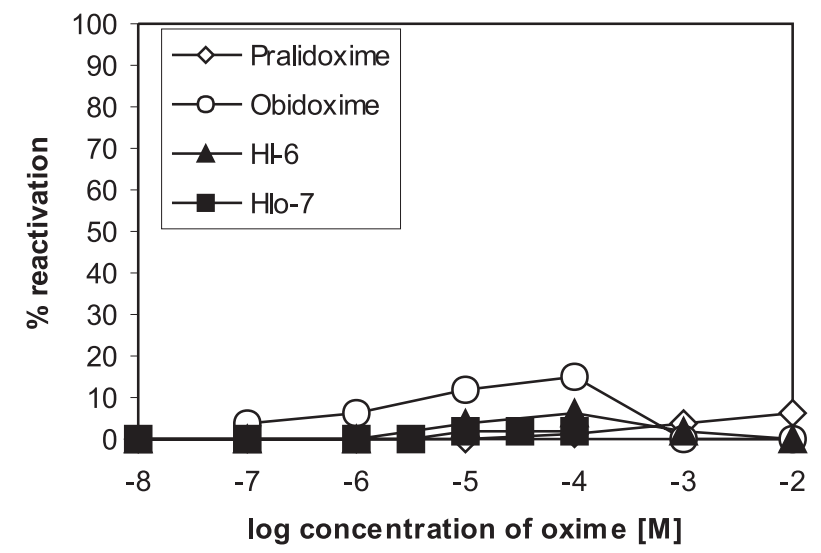

Fig. 3: Reactivation-concentration relationships of oximes to tabun-inhibited $\mathrm{AChE}$ - semilogarithmic transformation.

Tab. 3: Kinetic parameters of the reactivation of sarin-inhibited $\mathrm{AChE}$ in rat brain homogenate.

\begin{tabular}{|l|c|c|c|c|}
\hline Oxime & $\begin{array}{c}K_{\mathrm{DIS}} \\
{[\mu \mathrm{M}]}\end{array}$ & $\begin{array}{c}K_{\mathrm{R}} \\
{[\mu \mathrm{M}]}\end{array}$ & $\begin{array}{c}k_{\mathrm{R}} \\
{\left[\mathrm{min}^{-1}\right]}\end{array}$ & $\begin{array}{c}k_{\mathrm{r}} \\
{\left[\mathrm{min}^{-1} \mathrm{M}^{-1}\right]}\end{array}$ \\
\hline 2-PAM & 210 & 4360 & 0.290 & 67 \\
\hline Obidoxime & 280 & 2450 & 0.120 & 49 \\
\hline HI-6 & 24 & 389 & 0.390 & 1003 \\
\hline HLö-7 & 7 & 159 & 0.080 & 503 \\
\hline
\end{tabular}

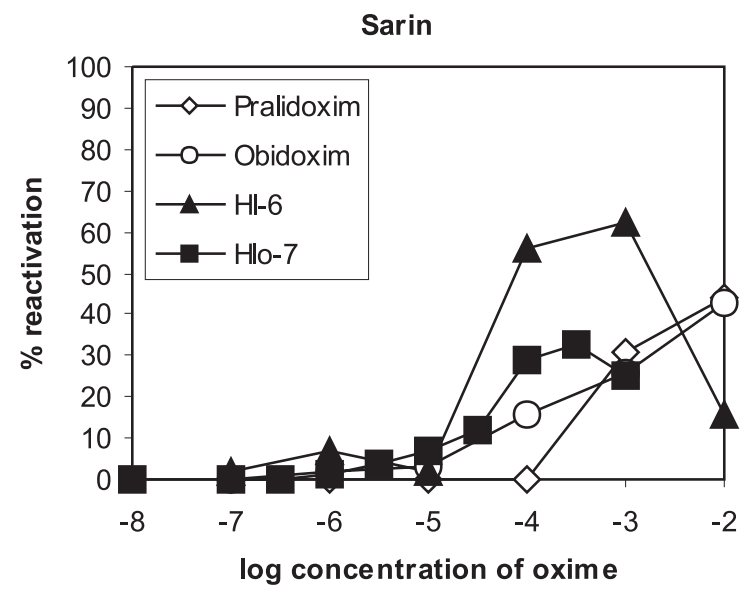

Fig. 4: Reactivation-concentration relationships of oximes to sarin-inhibited $\mathrm{AChE}$ - semilogarithmic transformation.
Tab. 4: Kinetic parameters of the reactivation of cyclosarininhibited $\mathrm{AChE}$ in rat brain homogenate.

\begin{tabular}{|l|c|c|c|c|}
\hline Oxime & $\begin{array}{c}K_{\mathrm{DIS}} \\
{[\mu \mathrm{M}]}\end{array}$ & $\begin{array}{c}K_{\mathrm{R}} \\
{[\mu \mathrm{M}]}\end{array}$ & $\begin{array}{c}k_{\mathrm{R}} \\
{\left[\mathrm{min}^{-1}\right]}\end{array}$ & $\begin{array}{c}k_{\mathrm{r}} \\
{\left[\mathrm{min}^{-1} \mathrm{M}^{-1}\right]}\end{array}$ \\
\hline 2-PAM & 210 & 12000 & 0.040 & 3 \\
\hline Obidoxime & 280 & - & - & - \\
\hline HI-6 & 24 & 12 & 0.350 & 29000 \\
\hline HLö-7 & 7 & 1000 & 0.008 & 8 \\
\hline
\end{tabular}

$(-)=$ not measurable values

\section{Cyclosarin}

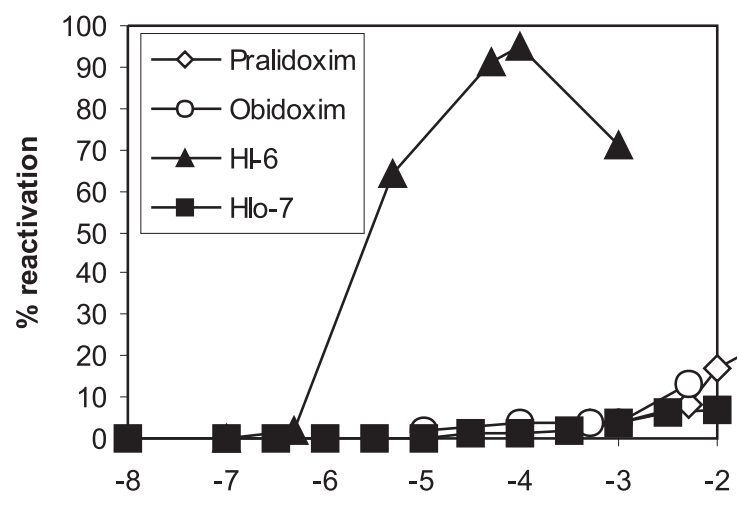

log concentration of oxime [M]

Fig. 5: Reactivation-concentration relationships of oximes to cyclosarin-inhibited AChE - semilogarithmic transformation.

Obidoxime is able to increase its reactivation potency at $10^{-3} \mathrm{M}$, nevertheless, this concentration is too high and toxic for human use.

Kinetics parameters in Tab. 2 characterize the ability of all studied oximes to reactivate tabun-inhibited AChE in vitro. Concentration-reactivation relationship is expressed in Figure 3. While kinetic parameters demonstrate relatively high affinity of obidoxime and HI-6 and low affinity of pralidoxime toward tabun-inhibited $\mathrm{AChE}$ and corresponding values of the second-order rate of reactivation of tabun-inhibited AChE, the potency of all above mentioned oximes to reactivate tabun-inhibited AChE is relatively low. The kinetic parameters for HLö-7 could not be measured because of its extremely low potency to reactivate tabun-inhibited AChE. According to the results shown in Figure 3, only obidoxime is able to cause $10 \%$ reactivation of tabun-inhibited $\mathrm{AChE}$ at $10^{-4} \mathrm{M}$, while pralidoxime and the oxime HLö-7 are completely ineffective and the oxime HI-6 is almost ineffective to reactivate tabun-inhibited AChE.

The ability of all studied oximes to reactivate sarin-inhibited $\mathrm{AChE}$ in vitro is demonstrated by kinetic parameters in Tab. 3 and by concentration-reactivation relationship expressed in Figure 4. The values of the dissociation constant $K_{R}$ indicates that the affinity of both $\mathrm{H}$ oximes (HLö-7 and HI-6) to the enzyme-inhibitor complex is approximately ten times higher compared to other studied oximes. The differences in the affinity of studied oximes to intact or inhibi- 
ted enzyme correspond to the differences in the second-order rate constant of reactivation of sarin-inhibited AChE $\left(\mathrm{k}_{\mathrm{r}}\right)$. According to our results shown in Figure 3, both $\mathrm{H}$ oximes are sufficiently effective to reactivate sarin-inhibited $\mathrm{AChE}$ at $10^{-4} \mathrm{M}$ that should be safe for human use, nevertheless, the potency of HI-6 to reactivate sarin-inhibited AChE is markedly higher compared to HLö-7. Other studied oximes (obidoxime and pralidoxime) are able to sufficiently reactivate sarin-inhibited $\mathrm{AChE}$ in vitro in higher concentration (from $10^{-3}$ to $10^{-2} \mathrm{M}$ ) that would be toxic for human use.

Kinetics parameters shown in Tab. 4 characterize the ability of all studied oximes to reactivate cyclosarin-inhibited $\mathrm{AChE}$ in vitro. Concentration-reactivation relationship is expressed in Figure 5. The dissociation constant $K_{R}$ indicates that the affinity of HI-6 to the enzyme-inhibitor complex is approximately 100 times higher compared to HLö-7 and 1000 times higher compared to pralidoxime. The differences in the affinity of studied oximes to cyclosarin-inhibited enzyme correspond to the big differences in the second-order rate constant of reactivation of cyclosarin-inhibited AChE $\left(\mathrm{k}_{\mathrm{r}}\right)$. The kinetic parameters for obidoxime could not be measured because of its extremely low potency to reactivate cyclosarin-inhibited AChE. According to our results shown in Figure 5, only the oxime HI-6 is sufficiently effective to reactivate cyclosarin-inhibited AChE in concentrations from $10^{-6}$ to $10^{-4} \mathrm{M}$ that should be safe for human use. On the other hand, HLö-7, obidoxime as well as pralidoxime are practically ineffective to reactivate cyclosarin-inhibited AChE in vitro.

\section{Discussion}

The efficacy of AChE reactivators depends on their reactivity and affinity to nerve agent-inhibited enzyme. Their reactivity is derived from the nucleophilic activity of oxime anion that is bound to the pyridinium ring (15). The affinity of oximes for intact enzyme, characterized by $\mathrm{K}_{\mathrm{dis}}$, and for nerve agent-inhibited enzyme, characterized by $K_{R}$, is derived from various physical features (steric compatibility, electrostatic effects, hydrophobic interactions) and from the shape and the size of the whole molecule as well as functional groups (13). The affinity of reactivators for nerve agent-inhibited $\mathrm{AChE}$ is considered to be the most important for their reactivating efficacy. Our results demonstrate that the strength of reactivator binding to AChE is usually decreased because of reduction of a space in the cavity of the AChE molecule following enzyme phosphonylation or phosphorylation. Practically all nerve agents reduce the strength of binding of oximes to AChE and, thus, make their nucleophilic effects more difficult $(8,9)$.

Despite of this fact, the oxime HLö-7 seems to be a very good reactivator of $\mathrm{VX}$ or sarin-inhibited $\mathrm{AChE}$ in vitro because its affinity for VX or sarin-inhibited AChE is relatively high and corresponds to the affinity of HI-6. Other studied oximes (pralidoxime, obidoxime) are also relatively good reactivators of VX-inhibited AChE (12) but their potency to reactivate sarin-inhibited $\mathrm{AChE}$ is lower compared to $\mathrm{H}$ oximes tested (HI-6, HLö-7) because their strength of binding to $\mathrm{AChE}$ phosphonylated by sarin is markedly smaller.

The in vitro potency of HLö-7 to reactivate cyclosarin or tabun-inhibited AChE is completely different from its ability to reactivate VX or sarin-inhibited AChE. HLö-7 has very low affinity for cyclosarin-inhibited AChE and, thus, its reactivating potency, found in vitro, is much lower in comparison with HI-6 and corresponds to pralidoxime and obidoxime. The oxime HI-6 is only sufficiently effective reactivator of cyclosarin-inhibited AChE among oximes studied because its strength of binding AChE phosphonylated by cyclosarin is not decreased compared to its affinity to intact AChE. In addition, the oxime HI-6 has been also considered to be sufficiently effective oxime against cyclosarin poisoning in vivo (16).

The potency of HLö-7 to reactivate tabun-inhibited $\mathrm{AChE}$ is also very low. Generally, tabun-inhibited AChE is extraordinarily difficult to reactivate because of the existence of a lone electron pair located on an amidic group that makes the nucleophilic attack of monopyridinium as well as bispyridinium oximes almost impossible $(2,4,6)$. The reactivating efficacy of bispyridinium oximes depends on the chemical structure of a bridge connecting both pyridinium rings, the position of oxime groups and the chemical structure of the substituent situated on the second pyridinium ring (19). This fact can explain relatively low efficacy of both $\mathrm{H}$ oximes (HI-6, HLö-7) against tabun because they contain ether bridge and carbamide group instead of the oxime group on the second pyridinium ring. On the other hand, the potency of obidoxime to reactivate tabun-inhibited AChE is higher compared to both $\mathrm{H}$ oximes because of more suitable position of both oxime groups.

Our results confirm that it is very difficult to find a broadspectrum oxime suitable for the antidotal treatment of poisoning with all highly toxic organophosphorus agents. The oxime HLö-7 so promising oxime against some fluorophosphonates such as soman and sarin (7) is practically ineffective to reactivate cyclosarin and tabun-inhibited AChE. Therefore, the oxime HLö-7 is not a more suitable oxime for antidotal treatment of people exposed to nerve agents than HI-6 according to the evaluation of its in vitro reactivating efficacy.

\section{Acknowledgements}

The study was supported by the grant of Ministry of Defense OBVLAJEP20032.

\section{References}

1. Bajgar J, Fusek J, Vachek J. Treatment and prophylaxis against nerve agent poisoning. ASA Newslett 1994;94-4:10-1

2. Cabal J, Kuča K, Kassa J. Specification of the structure of oximes able to reactivate tabun-inhibited acetylcholinesterase. Pharmacol Toxicol 2004;95:81-6. 
3. Dawson RM. Review of oximes available for treatment of nerve agent poisoning. J Appl Toxicol 1994;14:317-31.

4. Eto M. Organophosphorus pesticides: organic and biological chemistry. Cleveland: CRC Press Inc., 1976:342.

5. Inns RH, Leadbeater $\mathrm{L}$. The efficacy of bispyridinium derivatives in the treatmen of organophosphonate poisoning in the guinea pig. J Pharm Pharmacol 1983; $35: 427-33$.

6. Jokanovic M., Maksimovic M, Kilibarda V, Jovanovic D, Savic D. Oxime-induced reactivation of acetylcholinesterase inhibited by phosphoramidates. Toxicol Let 1996;85:35-9.

7. Kassa J. Review of oximes in the antidotal treatment of poisoning by organophosphorus nerve agents. J Toxicol-Clin Toxicol 2002;40:803-16.

8. Kassa J, Cabal J. A comparison of the efficacy of a new asymmetric bispyridin um oximes BI-6 with currently available oximes and $\mathrm{H}$ oximes against soman by in vitro and in vivo methods. Toxicology 1999;132:111-8.

9. Kassa J, Cabal J. A comparison of the efficacy of acetylcholinesterase reactivators against cyclohexyl methylphosphonofluoridate (GF agent) by in vitro and in vivo methods. Pharmacol Toxicol 1999;84:41-5.

10. Koplovitz I, Stewart JR. A comparison of the efficacy of HI-6 and 2-PAM agains soman, sarin and VX in the rabbit. Toxicol Lett 1995;70:269-79.

11. Kuča K, Kassa J. A comparison of the ability of a new bispyridinium oxime - 1(4-hydroxyiminomethylpyridinium)-4-(4-carbamoylpyridinium) butane dibromide and currently used oximes to reactivate nerve agent-inhibited rat brain acetylcholinesterase by in vitro methods. J Enzyme Inhib Med Chem 2003; 18:529-35.

12. Kuča K, Kassa J. Oximes-induced reactivation of rat brain acetylcholinesterase inhibited by VX agent. Hum Exp Toxicol 2004;23:167-71.

13. Kuča K, Patočka J, Cabal J. Reactivation of organophosphate inhibited acetycholin-esterase activity by $\alpha, \omega$-bis-(4-hydroxyiminomethylpyridinium) alkanes $i$ vitro. J Appl Biomed 2003;1:207-11.
14. Marrs TC. Organophosphate poisoning. Pharmacol Ther 1993;58:51-66.

15. Shih T-M. Comparison of several oximes on reactivation of soman-inhibited blood, brain and tissue cholinesterase activity in rats. Arch Toxicol 1993;67:637-46.

16. Ševelová L, Kuča K, Krejčová G, Vachek J. Therapeutic efficacy of oxime treatment in cyclosarin-poisoned mice pretreated with a combination of pyridostigmine, benactyzine and trihexyphenidyle. J Appl Biomed 2004;2:163-7.

17. Taylor, P. Anticholinesterase agents. In: J.G. Hardman, L.E. Lombird (eds.): The pharmacological basis of therapeutics. New York, McGraw Hill:1996: pp. $161-76$

18. Wang EIC, Braid PE. Oxime reactivation of diethylphosphoryl human serum cholinesterase. J Biol Chem 1967;242:2683-7.

19. Worek F, Widmann R, Knopff O, Szinicz, L. Reactivating potency of obidoxime pralidoxime, HI-6 and Hlö-7 in human erythrocyte acetylcholinesterase inhibited by highly toxic organophosphorus compounds. Arch Toxicol 1998;72:237-43.

Submitted December 2004.

Accepted May 2005.

Doc. MUDr. Jiři Kassa, CSc.,

P.O. Box 35/T,

Faculty of Military Health Sciences, 50001 Hradec Králové,

Czech Republic. e-mail: kassa@pmfhk.cz 